\title{
Fixed Bed Reactors for the Cultivation of Mammalian Cells: Design, Performance and Scale-Up
}

\author{
R. Pörtner ${ }^{*}$, , O.B. Platas ${ }^{1}$, D. Fassnacht ${ }^{1}$, D. Nehring ${ }^{2}$, P. Czermak ${ }^{2}$ and H. Märk1 ${ }^{1}$ \\ ${ }^{1}$ Institute of Bioprocess and Biosystems Engineering, Hamburg University of Technology, Germany \\ ${ }^{2}$ University of Applied Sciences Giessen-Friedberg, Institute of Biopharmaceutical Technology, Germany
}

\begin{abstract}
Fixed-bed reactors have gained growing attention for the cultivation of mammalian cells. They allow for a low shear stress cultivation of adherent and non-adherent cells due to the immobilization of cells within macroporous carriers. Their potential has been demonstrated for many cell culture purposes. Some of the recent developments are presented in this review, including improved antibody production by hybridoma cells, high performance cultivation of a hepatoblastoma cell line and cultivation of cells for the production of retroviral vectors. Furthermore, criteria for the selection of process strategies and scale-up concepts are addressed.
\end{abstract}

\section{INTRODUCTION}

Mammalian cells are used in industry as well as in research for a variety of applications. Examples include the production of monoclonal antibodies by hybridoma cells, therapeutic and diagnostic glyco-proteins by recombinant cells, production of retroviral vectors for gene therapy, and the cultivation of tissue cells for artificial organs [1]. Even if the majority of production systems are based on stirred tank reactors, reactor systems like fixed bed reactors which allow immobilization of cells have been gaining growing attention for a number of applications [2-4]. In vivo, cells are immobilized in tissues and organs and are perfused by lymph, blood, etc. In vitro systems, immobilization is primarily used to increase the stability and process intensity of the culture. Fixed-bed reactors have shown their potential in the establishment of optimum culture conditions for many cell culture purposes. Some of the recent developments are presented here, including improved antibody production by hybridoma cells, high performance cultivation of a hepatoblastoma cell line and cultivation of cells for the production of retroviral vectors. Furthermore, criteria for the selection of process strategies and scale-up concepts are addressed.

\section{DESIGN OF FIXED BED REACTORS}

A fixed-bed reactor consists of a vessel filled or packed with carrier material used as support for the immobilization of cells, and a conditioning vessel that contains the culture medium (Fig. 1, right). Both units are coupled via a circulation loop through which oxygen enriched medium is pumped from the conditioning vessel through the fixed-bed and back, while the cells (adherent or non-adherent) are retained in the fixed-bed. In the conditioning vessel, the exhausted productcontaining medium is exchanged batch wise or continuously [2]. An axial pumping of the media through the fixed-bed provides the cells with fresh media and oxygen upto fixedbed lengths of approx. $15 \mathrm{~cm}$. Due to possible oxygen limitation, larger fixed-bed volumes require the medium flow

*Address correspondence to this author at the Institute of Bioprocess and Biosystems Engineering, Hamburg University of Technology, Germany; Email: poertner@tuhh.de through the bed to be radial (Fig. 1, left) [5-11]. For easier handling, sterilization and scale-up, the fixed bed can be integrated to the conditioning vessel, making it a more compact unit. This type of reactor has been built upto $25 \mathrm{~L}$ of fixed bed volume.

Due to low shear stress, immobilization promotes the application of serum- or protein-free medium. It allows an easier medium exchange and reduces the steps of downstream processing. With a simple, and easy-to-handle reactor design, fixed bed reactor systems enable a high volume specific cell density $\left(10^{8}\right.$ cells $\left.\mathrm{mL}^{-1}\right)$ and productivity for the production of biopharmaceuticals over long periods of time (see below). Of special importance is the improved culture stability through immobilization [12-15].

\section{CARRIERS}

Immobilization occurs when organisms are entrapped in the interstices of porous particles or within gels and membranes. Carriers can be divided into two main groups-organic and inorganic. Suitable carriers for the immobilization of animal cells must fulfill certain requirements such as high surface to volume ratio, simple and non-toxic immobilization, optimal diffusion from the bulk phase to the center of the carrier, mechanical stability and $\mathrm{pH}$ stability. They should be steam sterilisable, reusable and suitabile for adherent and non-adherent cells.

A large number of macroporous carriers and support materials for immobilization have been suggested, including glass (natron, borosilicate) [13, 16-21], collagen [22], synthetic materials, e.g. polypropylene, polyurethane [23-31] or ceramics [own data, not published]. Most of these carriers proved to be suitable for a large number of cell types (e.g. hybridoma, $\mathrm{CHO}$, hepatocytes etc., compare Fig. 2). In some cases (e.g. carriers made of glass or cellulose) coating with gelatine was recommended to support growth of strictly adherent cells [18, unpublished data].

The properties of the cells and the mode of cultivation carried out defines the type of carrier to be chosen. Thus, carriers of diameters below $0.3 \mathrm{~mm}$ (microcarriers) are used mainly for the cultivation of adherent cells in suspension, carriers between 0.3 and $1 \mathrm{~mm}$ are appropriate for fluidized- 


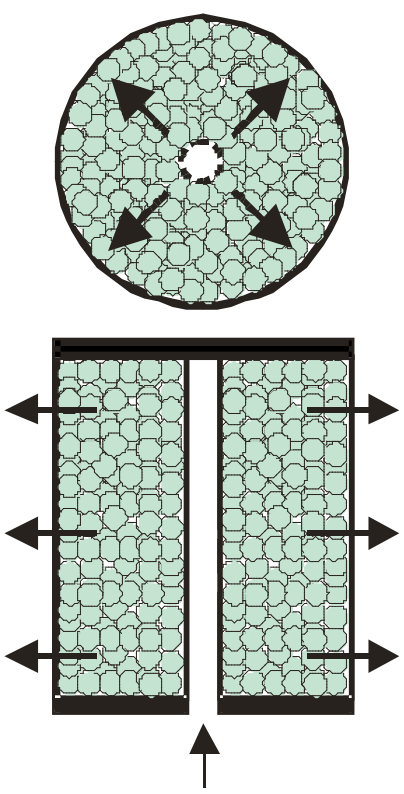

Radial flow good scale-up

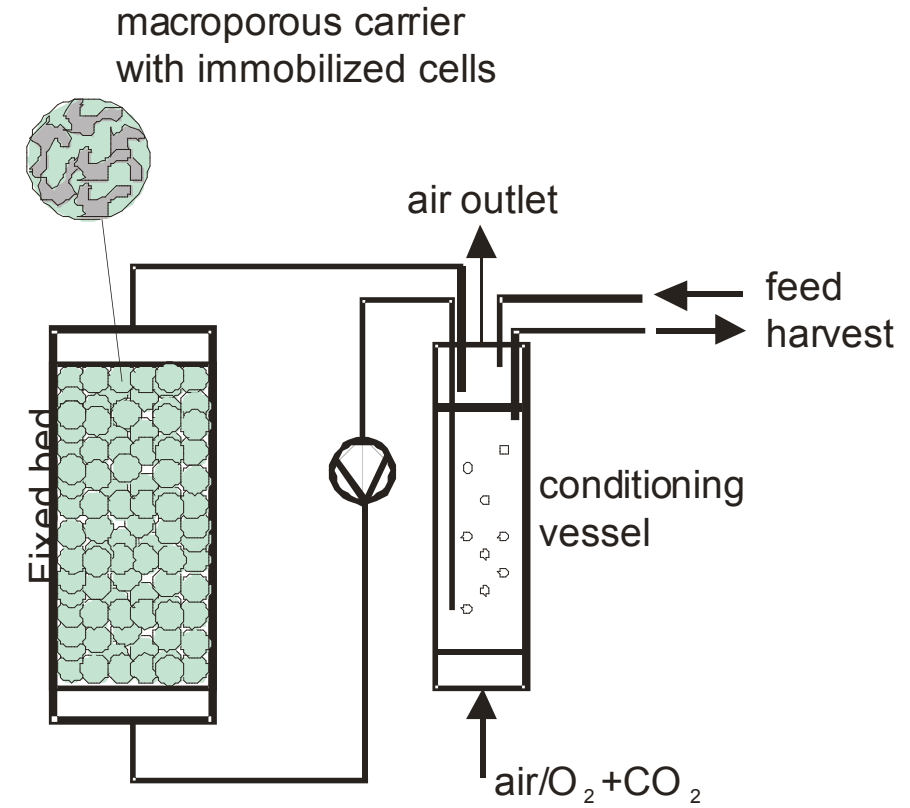

Axial flow

max. length appr. $15 \mathrm{~cm}$ laboratory scale

Fig. (1). Schematic diagram of a fixed-bed reactor system. Right: Axial-flow fixed-bed system. Left: Radial-flow fixed bed for scale-up.

beds, and those sizes above $1 \mathrm{~mm}$ are used in fixed-bed systems.
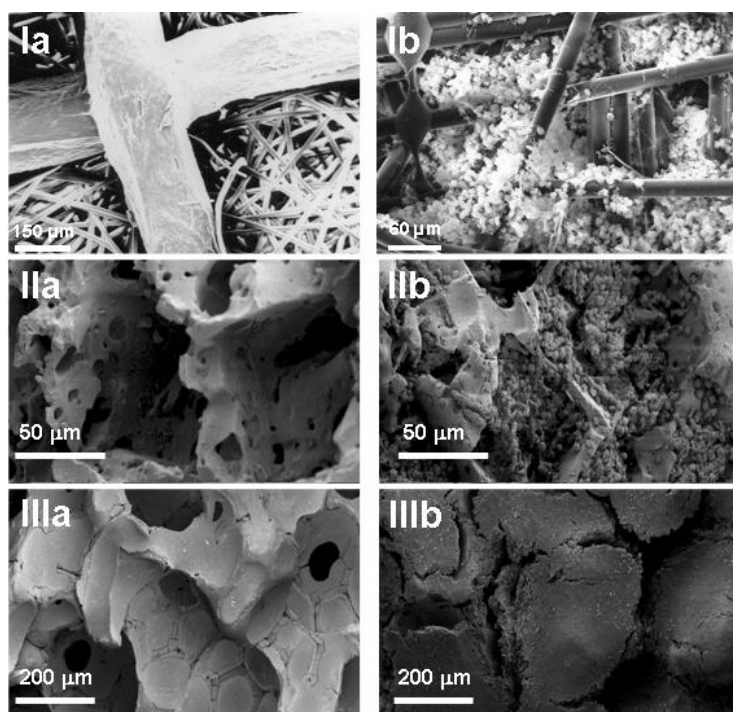

Fig. (2). Examples for macroporous carriers. I: Fibra-Cel ${ }^{\mathrm{TM}}$ (New Brunswick, Germany), Ia: native carrier, Ib: CHO-K1 cells growing on the carrier. II: Glass carrier $\operatorname{SIRAN}^{\circledR}$ (QVF, Germany), IIa: native carrier, IIb: hybridoma cells within the carrier. III: Ceramic carrier SPONCERAM ${ }^{\circledR}$ (Zellwerk GmbH). IIIa, native carrier surface, IIIb: hepatoblastoma cells growing within the carrier.

\section{APPLICATIONS AND DESIGN CRITERIA}

\section{Overview}

Fixed bed reactors have been successfully used for a wide range of cell lines and their applications. Whereas the earlier studies focused on the production of biopharmaceuticals as an alternative to suspension reactors or hollow fiber systems, new applications can be found in other areas including gene and cell therapy and tissue engineering. Some of the recent developments in fixed bed reactor technology are presented in Table 1.

\section{Fixed Bed Cultivation at Increased Oxygen Levels}

The heterogeneity inside the carriers, i.e. the nutrient, metabolite and biomass concentration gradients along the radius of the carrier can limit productivity. These gradients are due to the substrate or oxygen consumption of the immobilized cells. If the diffusion rate of an important substrate into the carrier is slow compared to the reaction rate, limitation might occur. The opposite can happen with products which accumulate to inhibiting concentrations inside the carrier (e.g. carbon dioxide). Fassnacht and Pörtner [33] used an oxygen reaction-diffusion model to describe and optimize the performance of axial-flow as well as radial-flow fixedbeds. Furthermore, they could show that an increased oxygen level can significantly improve the performance of a fixed bed reactor. A $100 \mathrm{~mL}$ fixed-bed reactor was operated with a hybridoma cell line at high dilution rates between 10 and 20 $\mathrm{L}$ medium per $\mathrm{L}$ of fixed-bed volume per day. At these extremely high perfusion rates, the volume specific glucose uptake rate as well as the production rate of monoclonal antibodies were upto two times higher than when the medium was sparged with 21,42 or $63 \%$ oxygen enriched air. Although dissolved oxygen concentrations higher than air saturation are usually considered to be toxic for animal cells in suspension cultures [46], it was found that this was not the case for fixed bed systems.

\section{Cultivation of Hepatocytes}

In order to develop a bioartificial liver (BAL), many authors have attempted to optimize hepatocyte cultures at 
Table 1. Successful Applications of Fixed Bed Reactors for Cultivation of Mammalian Cells

\begin{tabular}{|l|l|l|}
\hline \multicolumn{1}{|c|}{ Type of Cell } & \multicolumn{1}{|c|}{ Product/Purpose } & Ref. \\
\hline \hline Hybridoma & Monoclonal antibodies & {$[5,16,19,24,31-33]$} \\
Transfectoma & Chimeric fragmented antibodies & {$[7,13]$} \\
rBHK & Glycosylated antibody-cytokine & {$[34,48]$} \\
CHO & NMR-studies & {$[35,36]$} \\
& Rec. Erythropoietin & {$[21]$} \\
rCHO & Rec. human placental alkaline phosphatase (SEAP) & {$[37]$} \\
VERO & & {$[36]$} \\
L293 & Rec. protein & own data \\
HeLa & Vaccine & {$[38]$} \\
NIH3T3 & & own data \\
Insect cells & Baculovirus & {$[9,39]$} \\
Packaging cell lines & Recombinant protein & {$[28,40-43]$} \\
Immortalized hepatocytes & Retrovirus production & {$[10,11,20,25,29,44,45]$} \\
Primary hepathocytes & Bioartificial liver & {$[23,26,30]$} \\
Human kidney cells & Bioartificial liver & own data \\
Human melanoma cells & Membrane vesicles & own data \\
\hline
\end{tabular}

high cell densities in different cultivation systems trying to mimic tissue-like growth (compare Table 1). However, compared to cell lines with higher adaptability to culture such as hybridomas and other cell lines, hepatocytes are considered to be one of the most difficult cell types to be cultivated in an artificial environment.

The fact that the human hepatocellular carcinoma cell lines like Hep-G2 secrete the major plasma proteins and the hepatitis B surface antigen, has directed the attention towards these cell lines for research purposes. They have a potential use in screening systems, where cultures of these cells are subjected to the effects of different substances such as new drugs or toxic metabolites. The future of these techniques is the partial replacement of animal and clinical trials, in which the complicated process of blood screening and ethics during research are of major importance, by culture systems of human cells.

An example for fixed bed cultivation of the hepatoblastoma cell line Hep-G2 is shown in Fig. (3), where different culture conditions were applied during 24 days of cultivation. Continuous perfusion of medium in the conditioning vessel was started when glucose became limiting. A higher glutamine concentration marginally increased the substrate uptake rate during continuous culture. An oxygen supply at $200 \%$ air saturation and a dilution rate of $\mathrm{D}_{\mathrm{FB}}=8 \mathrm{~d}^{-1}$ after 20 days of culture significantly increased the substrate consumption rates. This successful example underlines again the importance of proper selection of process parameters such as perfusion rates and oxygen level.

\section{Production of Retroviral Vectors for Somatic Gene Therapy}

A number of examples of successful application of fixed bed reactors for the production of high titer retroviral vectors for gene therapy can be found in the literature (compare

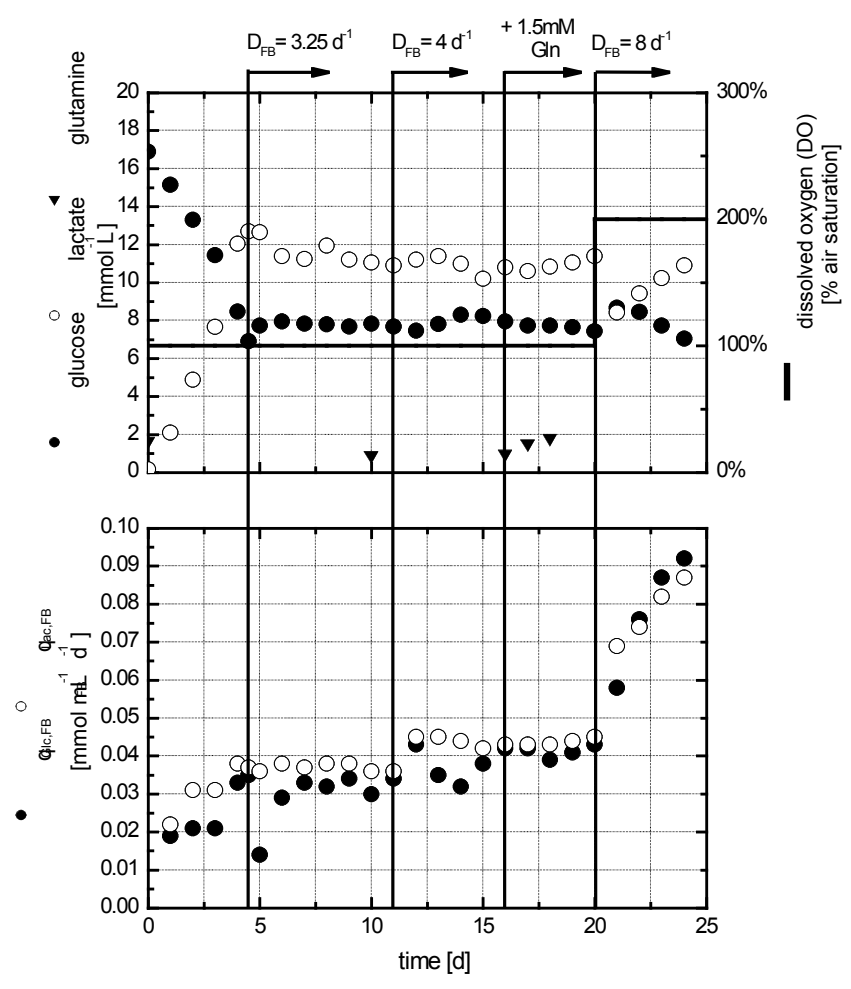

Fig. (3). Cultivation of the Hep-G2 in a $100 \mathrm{~mL}$ axial-flow fixedbed reactor. Top: Glucose $(\bullet)$, lactate $(\circ)$ and glutamine $(\boldsymbol{\Delta})$ concentrations as well as the relative oxygen percentage at the air inlet $(-)$. Bottom: Glucose uptake rate $(\bullet)$ and the lactate production rate $(\circ)$ during the culture. The vertical lines indicate the different dilution rates and conditions during the 24 days of culture. FB: fixed bed.

Table 1). Pseudotype vectors are used for gene transfer in many gene therapy approaches. But still, low vector concentrations in standard batch cultures and high temperature dependent decay limit large-scale production. To overcome 
these obstacles, the kinetic relations of the bioreaction, cell growth and vector production in different culture modes need to be understood. Furthermore, not only generic optimization of the packaging cell line and the vector stability needs to be studied, but also the effective optimization of process modes.

Nehring et al. [28] used a mathematical model developed on the basis of experimental data measured in culture dishes. The kinetics of cell growth, nutrient consumption and vector production and decay was applied to analyse different process modes and to optimize the cultivation and harvest strategy during fixed bed operation. The optimization with the aid of the model led to the conclusion that optimizing the harvest cycles and feed flows resulted in a higher yield in comparison to batch or fed batch modes.

Retroviral pseudotype vectors derived from the murine leukaemia virus carrying the HIV-1 envelop protein MLV (HIV-1) were produced using a $200 \mathrm{ml}$ fixed bed reactor for high cell density cultivation on macro-porous carriers. Reasonable optimal parameters calculated with the help of the model were applied to run the cultivation. After starting the cultivation in batch mode, the reactor was either run in perfusion, perfused fed-batch or repeated-batch. The different culture modes are compared in Table $\mathbf{2}$. Whereas the highest maximal end point titer was measured in perfusion mode, the highest medium related productivity was achieved in repeated batch mode. Sensitivity analysis performed based on the results of the optimization showed that under optimal conditions, the final concentration and the yield of the entire process is more sensitive to the parameters of process operation than to the bioreaction due to the fast degradation of replication competent pseudo-type vectors.

\section{Scale-Up}

Scale-up is a major demand for high-yield stable bioprocess systems in mammalian cell culture-based biopharmaceutical production processes $[32,33,35,47]$. Using the concept of a radial flow geometry, Fassnacht and Pörtner [33] demonstrated a scale-up from $100 \mathrm{~mL}$ to $5 \mathrm{~L}$ of fixed bed volume. As perfusion rates of $10 \mathrm{~L}$ medium per $\mathrm{L}$ of fixed-bed volume per day correspond to a medium flow rate of approx. $50 \mathrm{~L}$ per day for a 5 L-reactor, this reactor size can be regarded as pilot scale. Further optimization of the fixed bed process can be achieved by reducing the inoculum volume [8]. For this, it is crucial to reduce the initial cell density to a minimum without affecting exponential growth as well as to increase the bed volume in the reactor during the fermentation process. The combination of a low cell- density inoculum and a cultivation strategy where the surface area for cell growth can be increased progressively might reduce the number of pre-culture steps needed before starting up a cell culture process. Inoculation means not only the cell density to be inoculated, but also the working volume of the reactor to be inoculated. From batch cultures performed in a $10 \mathrm{~mL}$ fixed-bed reactor, a cell density of $5 \cdot 10^{4}$ cells $\mathrm{mL}^{-1}$ of medium volume was obtained as an optimal value with respect to growth rate within the fixed bed (own data, not published). In suspension culture, usually 1-2 $10^{6}$ cells $\mathrm{mL}^{-1}$ are required.

To further reduce the inoculum volume in fixed-bed reactor, the "Inoculation during Cultivation" strategy can be applied. This strategy consists of partially filling the conditioning vessel with medium at the beginning of the cultivation where only a fraction of the fixed-bed is submerged and therefore active. Only this submerged part of the fixed-bed is then inoculated with a low initial cell density. After a short cultivation period the initial cell density is increased and the medium level within the conditioning vessel is raised to another desired height. This activates the fresh part of the fixed-bed which is then inoculated by the low number of cells that are washed out of the carriers during cultivation. The maximal cell density is then finally reached during the culture.

This strategy was successfully applied in a $5.6 \mathrm{~L}$ radial flow fixed-bed reactor. The start-up phase was divided into three steps with each step covering one third of the fixed-bed in the reactor. With a very low initial cell density of $5 \cdot 10^{4}$ cells $\mathrm{mL}^{-1}$ (harvested from 2 roller bottles) for the type of fixed bed reactor used, it was possible to start the cultivation. The reactor has already been operated at cell densities higher than $5 \cdot 10^{7}$ cells $\mathrm{mL}^{-1}$ of fixed bed volume, which is an increase in cell density of more than 1300 folds. This is at least one order higher compared to suspension reactors run in fedbatch or continuous perfusion modes. Therefore, with this pilot scale reactor system, a significant reduction of the preinoculation steps was achieved. The reduction of the number of cells to be inoculated into a fixed bed reactor by means of the optimization of the initial cell density and by means of scaling-up strategies will lead to the reduction of the inoculation steps during the cultivation cascades in industrial processes.

\section{CONCLUSIONS}

Fixed bed reactors have underlined their potential for the cultivation of mammalian cells for a large number of applications ranging from the production of biopharmaceuticals to tissue engineering and gene therapy. With respect to produc-

Table 2. Fixed-Bed Cultivation of the Retroviral Packaging Cell Line TELCeB6/pTr712-K52S (Comparison of Different Process Strategies (Data from [28]))

\begin{tabular}{|c|c|c|c|c|}
\hline & Perfusion & Repeated Fed Batch & Repeated Batch & Flask Culture \\
\hline Total time $[\mathrm{h}]$ & 412 & 414 & 418 & 24 \\
\hline Total medium amount [1] & 12,66 & 11,74 & 18,27 & 0,01 \\
\hline Final cell number $\left[10^{9}\right.$ cells $]$ & 2.64 & 2.08 & 5.42 & 0.00748 \\
\hline Total vector production $\left[10^{8} \mathrm{cfu}\right]$ & 27.6 & 9.43 & 46.4 & 0.0140 \\
\hline Maximal vector titer $\left[10^{6} \mathrm{cfu} \mathrm{ml}^{-1}\right]$ & 6.7 & 2.28 & 11.1 & 0.0583 \\
\hline
\end{tabular}


tion of biopharmaceuticals, advantages can be seen in (i) high volume specific cell density, (iii) high volume specific productivity during long-term cultures, (iii) low shear forces, (iv) simple medium exchange and cell / product separation, (v) simple scale-up with radial-flow geometry. Compared to suspension reactors which are still the preferred type of reactor system on industrial scale, fixed bed reactors can be regarded as reliable, multipurpose production systems. Whereas the cultivation of production cell lines in suspension often requires extensive optimization of medium and cell line (e.g. tolerance to shear stress) or process conditions (stirrer speed, aeration rate), most cell lines can be cultivated in fixed bed reactors without further adaptation. Therefore, advantages of this technology can especially be seen in those cases, where non optimized cell lines or media are applied (e.g. for production of small quantities of product for cell line selection or clinical trials). A further advantage can also be seen in the reduced pre-culture steps compared to suspension reactors.

Applications in the field of tissue engineering and gene therapy, where usually adherent cells are used and tissue like structures are required, will further promote the use of fixed bed reactors.

\section{REFERENCES}

[1] Otzturk SS. Cell Culture Technology-An Overview. In: Ozturk SS, Hu W-S (eds.), Cell Culture Technology For Pharmaceutical and Cell-Based Therapies. Taylor \& Francis Group, New York, 2006.

[2] Pörtner R. Reaktionstechnik der Kultur tierischer Zellen. Shaker Verlag. Aachen, 1998

[3] Pörtner R, Märk1 H, Fassnacht D. Immobilization of Mammalian Cells in Fixed Bed Reactors. Bioforum. Bioresearch plus Biotechnology. G.I.T. Verlag, Darmstadt, Germany, 1999.

[4] Review: Meuwly F, Ruffieux P-A, Kadouri A, von Stockar U. Packed-bed bioreactors for mammalian cell culture: Bioprocess and biomedical applications. Biotechnol Adv 2007; 25(1): 45-56.

[5] Bohmann A, Pörtner R, Märkl H. Performance of a membrane dialysis bioreactor with radial-flow fixed bed for the cultivation of a hybridoma cell line. Appl Microbiol Biotechnol 1995; 43: 77280.

[6] Pörtner R, Lüdemann I, Märkl H. Dialysis cultures with immobilized hybridoma cells for effective production of monoclonal antibodies. Cytotechnology 1997; 23: 39-45.

[7] Pörtner R, Lüdemann I, Reher K, Neumaier M, Märk1 H. Fixed-bed dialysis culture of a transfectoma cell line producing chimeric Fabfragments with "nutrient-split"-feeding strategy. Biotechnol Techn 1998; 12: 501-5.

[8] Fassnacht D. Fixed-Bed Reactors for the Cultivation of Animal Cells. VDI Verlag GmbH, Düsseldorf, 2001.

[9] Kwon MS, Kato T, Dojima T, Park EY. Application of a radialflow bioreactor in the production of beta1,3-N-cetylglucosaminyltransferase-2 fused with GFPuv using stably transformed insect cell lines. Biotechnol Appl Biochem 2005; 42: 41-6.

[10] Hongo T, Kajikawa M, Ishida S, et al. Three-dimensional highdensity culture of HepG2 cells in a 5-ml radial-flow bioreactor for construction of artificial liver. J Biosci Bioeng 2005; 99: 237-44.

[11] Iwahori T, Matsuno N, Johjima Y, et al. Radial flow bioreactor for the creation of bioartificial liver and kidney. Transplant Proc 2005; 37: 212-4.

[12] Fussenegger M, Fassnacht D, Schwartz R, et al. Regulated overexpression of the survival factor bcl-2 in CHO cells increases viable cell density in batch culture and decreases DNA release in extended fixed-bed cultivation. Cytotechnology 2000; 32: 45-61.

[13] Lüdemann I, Pörtner R, Schaefer C, et al. Improvement of the culture stability of non-anchorage-dependent animal cells grown in serum-free media through immobilization. Cytotechnology 1996; 19: 111-24.

[14] Fassnacht D, Rössing S, Singh R, Al-Rubeai M, Pörtner R. Influence of BCL-2 Expression on antibody productivity in high cell density hybridoma culture systems. Cytotechnology 1999; 30: 95105.

[15] Moro AM, Rodrigues MT, Gouvea MN, Silvestri ML, Kalil JE, Raw I. Multiparametric analyses of hybridoma growth on glass cylinders in a packed-bed bioreactor system with internal aeration. Serum-supplemented and serum-free media comparison for MAb production. J Immunol Meth 1994; 176: 67-77.

[16] Looby D, Racher AJ, Griffiths JB, Dowsett AB. The immobilization of animal cells in fixed bed and fluidized porous glass sphere reactors. in Physiology of Immobilized Cells (de Bont, J.A.M., Visser, J., Mattiasson, B., and Tramper, J., eds.) Elsevier Science Publishers B.V., Amsterdam, Netherlands, 1990; 255-64.

[17] Yoshida H, Mizutani S, Ikenaga H. Production of monoclonal antibodies with a radial-flow bioreactor. In: Kaminogawa S, ed. (eds), Animal cell technology: basic and applied aspects; Kluwer Academic Publishers, Dordrecht, Boston, London, 1993; 347-53.

[18] Lüllau E, Biselli M, Wandrey C. Growth and metabolism of CHOcells in porous glass carriers. in: R.E. Spier, J.B. Griffiths and W. Berthold, Animal Cell Technology: Products of today, prospects of tomorrow, Butterworth-Heinemann, 1994; 252-5.

[19] Ong CP, Pörtner R, Märkl H, Yamazaki Y, Yasuda K, Matsumura M. High density cultivation of hybridoma in charged porous carriers. J Biotechnol 1994; 34: 259-68.

[20] Fassnacht D, Rössing S, Stange J, Pörtner R. Long-term cultivation of immortalised mouse hepatocytes in a high cell density fixed bed reactor. Biotechnol Techn 1998; 12: 25-30.

[21] Thelwall PE, Anthony ML, Fassnacht D, Pörtner R, Brindle KM. Analysis of cell growth in a fixed bed bioreactor using magnetic resonance spectroscopy and imaging. in New Developments and New Applications in Animal Cell Technology (Merten, O.W., Perrin, P., and Griffiths J.B., eds.), Kluwer Academic Publishers, The Netherlands, 1998; 627-33.

[22] Ray NG, Tung AS, Hayman EG, Vorunakis JN, Rundstadler PW. Continuous cell cultures in fluidized-bed bioreactors-cultivation of hybridomas and recombinant chines hamster ovary cells immobilized in collagen micropheres. Ann NY Sci 1990; 589: 443-57.

[23] Gion T, Shimada M, Shirabe K, et al. Evaluation of a hybrid artificial liver using a polyurethane foam packed-Bed culture system in dogs. J Surg Res 1999; 82: 131-36.

[24] Wang G, Zhang W, Jacklin C, Freedman D, Eppstein L, Kadouri A. Modified CelliGen-packed bed bioreactors for hybridoma cell cultures. Cytotechnology 1992; 9: 41-9.

[25] Ijima H, Nakazawa K, Mizumoto H, Matsushita T, Funatsu K. Formation of a spherical multicellular aggregate (spheroid) of animal cells in the pores of polyurethane foam as a cell culture substratum and its application to a hybrid artificial liver. J Biomater Sci Polym 1998; 9: 765-78.

[26] Kurosawa H, Yasumoto K, Kimura T. Polyurethane membrane as an efficient immobilization carrier for high-density culture of rat hepatocytes in the fixed-bed reactor. Biotechnol Bioeng 2000; 70: $160-6$.

[27] Miyoshi H, Yanagi K, Fukuda H, Ohshima N. Long-term continuous culture of hepatocytes in a packed-bed reactor utilizing porous resin. Biotechnol Bioeng 1994; 43: 635-44.

[28] Nehring D, Gonzalez R, Pörtner R, Czermak P. Experimental and modelling study of different process modes for retroviral production in a fixed bed reactor. J Biotechnol 2006; 122: 239-53.

[29] Kataoka K, Nagao Y, Nukui T, et al. An organic-inorganic hybrid scaffold for the culture of HepG2 cells in a bioreactor. Biomaterials 2005; 26: 2509-16.

[30] Yamashita Y, Shimada M, Tsujita E, et al. Polyurethane foam/spheroid culture system using human hepatoblastoma cell line (Hep G2) as a possible new hybrid artificial liver. Cell Transplant 2001; 10: 717-22.

[31] Yang ST, Luo J, Chen C. A fibrous-bed bioreactor for continuous production of monoclonal antibody by hybridoma. Adv Biochem Eng Biotechnol 2004; 87: 61-96.

[32] Golmakany N, Rasaee MJ, Furouzandeh M, Shojaosadati SA, Kashanian S, Omidfar K. Continuous production of monoclonal antibody in a packed-bed bioreactor. Biotechnol Appl Biochem 2005; 41: 273-8.

[33] Fassnacht D, Pörtner R. Experimental and theoretical considerations on oxygen supply for animal cell growth in fixed bed reactors. J Biotechnol 1999; 72: 169-84.

[34] Burger C, Carrondo MJ, Cruz P, et al. An integrated strategy for the process development of a recombinant antibody-cytokine 
fusion protein expressed in BHK cells. Appl Microbiol Biotechnol 1999; 52: 345-53.

[35] Ducommun P, Rueux PA, Kadouri A, von Stockar U, Marison IW. Monitoring of temperature effects on animal cell metabolism in a packed bed process. Biotechnol Bioeng 2002; 77: 838-42.

[36] Matsushita T, Ketayama M, Kamihata K, Funatsu K. Anchoragedependent mammalian cell culture using polyurethane foam as a new substratum for cell attachment. Appl Microbiol Biotechnol 1990; 33: 287-90.

[37] Deng J, Yang Q, Cheng X, Li L, Zhou J. Production of rhEPO with a serum-free medium in the packed bed bioreactor. Chin J Biotechnol 1997; 13: 247-52.

[38] Hu YC, Kaufman J, Cho MW, Golding H, Shiloach J. Production of HIV-1 gp120 in Packed-Bed Bioreactor Using the Vaccinia Virus/T7 Expression System. Biotechnol Prog 2000; 16: 744-50.

[39] Lu JT, Chung YC, Chan ZR, Hu YC. A novel oscillating bioreactor BelloCell: implications for insect cell culture and recombinant protein production. Biotechnol Lett 2005; 27:1059-65.

[40] Merten OW, Cruz PE, Rochette C, et al. Comparison of different bioreactor systems for the production of high titer retroviral Vectors. Biotechnol Prog 2001; 17: 326-35.

[41] Sendresen C, Fassnacht D, Benati C, Pörtner R. Possible strategies for the production of viral vector: the role of the engineering design. in Animal Cell Technology: From Target to Market: (Lindner-Olsson, E., Chatzissavidou, N. and Lüllau, E., eds.), Kluwer Academic Publishers, Dordrecht, Netherlands, 2001; 538-40.
[42] McTaggart S, Al-Rubeai M. Effects of culture parameters on the production of retroviral vectors by a human packaging cell line. Biotechnol Prog 2000; 16: 859-65.

[43] Forestell SP, Dando JS, Chen J, de Vries P, Bohnlein E, Rigg RJ. Novel retroviral packaging cell lines: complementary tropisms and improved vector production for efficient gene transfer. Gene Ther 1997; 4: 600-10.

[44] Akiyama I, Tomiyama K, Sakaguchi M, et al. Expression of CYP3A4 by an immortalized human hepatocyte line in a threedimensional culture using a radial-flow bioreactor. Int J Mol Med 2004; 14: 663-8.

[45] Kawada M, Nagamori S, Aizaki H, et al. Massive culture of human liver cancer cells in a newly developed radial flow bioreactor system: ultrafine structure of functionally enhanced hepatocarcinoma cell lines. In Vitro Cell Dev Biol Anim 1998; 34: 109-15.

[46] Simpson N, Milner A, Al-Rubeai M. Prevention of hybridoma cell death by Bcl-2 during suboptimal culture conditions. Biotechnol Bioeng 1997; 54: 1-16.

[47] Cong C, Chang Y, Deng J, Xiao C, Su Z. A novel scale-up method for mammalian cell culture in packed-bed bioreactor. Biotechnol Lett 2001; 23: 881-5.

[48] Chen YH, Wu JC, Wang KC, et al. Baculovirus-mediated production of HDV-like particles in BHK cells using a novel oscillating bioreactor. J Biotechnol 2005; 118: 135-147. 